\title{
SEMIOTIKA
}

Volume 19

Halaman $89-106$

URL: https://jurnal.unej.ac.id/index.php/SEMIOTIKA/index

E-ISSN: 2599-3429

P-ISSN: $1411-5948$

\section{CITRA EKSOTIK DALAM NOVEL RONGGENG DUKUH PARUK}

\author{
EXOTIC IMAGES IN RONGGENG DUKUH PARUK
}

\author{
Abu Bakar Ramadhan Muhamad \\ Fakultas Ilmu Budaya, Universitas Jember \\ Corresponding Author: alfi_nh@yahoo.com
}

Informasi Artikel:

Dikirim: 23/3/2018; Direvisi: 20/4/2018; Diterima: 27/5/2018

\begin{abstract}
Imaging of a discourse in the paradigm of postcolonialism is closely related to the issue of domination and subordination in terms of reference to imperialism or capitalization. The imagery is a project that develops special perceptions about "foreign" (East) regions. This project presupposes that the "foreign" (East) region is exotic "uncivilized" regions, standardized in a special "understanding", whose main purpose is to separate or dissolve it ("tame" the "foreign" region), so that different from or being "civilized". One area that is strongly embedded in this project is literature, with the novel as an aesthetic object. In connection with this issue, this article reveals how the East is presented in its exotic image, so how the image represents an ambivalent relationship between the East (colonized) and the West (invaders), especially in the Ronggeng Dukuh Paruk (RDP) novel by Ahamad Tohari.The results of the study show that the RDP novel is an urgent medium related to the conditions of postcoloniality. The postcoloniality is meant not only that the narrative that is displayed is the essence of what is obtained from the author about the exotic world region (the nature of Paruk dukuh) with all the signs attached to it, narration is also used as an affirmation of identity and historical existence, in the context of civilized culture. The culture in question is the source of identity that is championed as a filter and lifter, for the community that has been known and thought about, as an invitation for emancipation. Power and ability to tell stories, in this case, are used as weapons of the author in hopes of inspiring readers. The expected result is the hegemonic reader of the discourse displayed in the work of the author.In the post-colonial context, this method is inseparable from a combination where political and ideological power is interrelated, where the image represented is always still signifying the "emancipation" power relationship between the West and the East. However, like ideology, imaging must be realized other than as originating from and relating to material conditions and material effects, it is also a misrepresentation of reality and in its rearrangement process. Therefore, the potential, possibilities, and certain visions that follow, are full of content, values, or strategies for "mastering" (power). Especially in the Ronggeng Dukuh Paruk novel by Ahamad Tohari, exotic images give rise to ambivalent meanings for emancipation efforts (West to East).
\end{abstract}

Keywords: ambivalence, emancipation, exoticis, novel, postcolonialism 


\begin{abstract}
Abstrak
Pencitraan suatu wacana dalam paradigma poskolonialisme, erat hubungannya dengan persoalan dominasi dan subordinasi dalam kerangka referensi imperialisme ataupun kapitaslisme. Berkaitan dengan itu, artikel ini mengungkap bagaimana Timur dihadirkan dalam citra eksotiknya, hingga pencitraan tersebut merepresentasikan hubungan yang ambivalen antara pihak Timur (terjajah) dan Barat (penjajah), khususnya dalam novel Ronggeng Dukuh Paruk (RDP) karya Ahamad Tohari. Hasil kajian menunjukkan, novel $R D P$ adalah media yang urgen berkaitan dengan kondisikondisi poskolonialitas. Poskolonialitas adalah narasi yang ditampilkan dan inti dari apa yang diperoleh dari penulisnya tentang wilayah dunia yang eksotik (kealamian dukuh Paruk) dengan segala tanda yang melekatinya. Narasi juga dipergunakan sebagai penegasan jati diri dan eksitensi sejarah, dalam konteks kebudayaan yang beradab. Dalam konteks pasca-kolonial, cara ini tidak terlepas dari paduan yang kuasa politis dan ideologis saling terkait, citra yang direpresentasikan senantiasa masih mengisyaratkan hubungan kekuatan "emansipasi” antara Barat dan Timur. Akan tetapi, seperti ideologi, pencitraan harus disadari selain berasal dari dan berkaitan dengan keadaan-keadaan material serta efek-efek material, juga merupakan suatu kekeliruan gambaran realitas dan dalam proses penataan ulangnya. Oleh karena itu, potensi, kemungkinan, dan visi tertentu yang mengikutinya, sarat dengan muatan-muatan, nilai-nilai, ataupun strategistrategi untuk "menguasai" (kekuasaan). Khususnya dalam novel Ronggeng Dukuh Paruk karya Ahamad Tohari, citra eksotik memunculkan makna ambivalen bagi usahausaha emansipasi (Barat terhadap Timur).
\end{abstract}

Kata kunci: ambivalensi, eksotisme, emansipasi, novel, poskolonialisme.

\title{
PENDAHULUAN
}

Gandhi (2001:91-92) menyatakan, dalam pengetahuan Barat, Timur adalah rangsangan kognitif esensial dalam membentuk hipotesis tentang sifat-sifat "ketimuran". Bahan dihasilkan tidak hanya berbentuk pengalaman ataupun pengetahuan "baru" dan "berbeda" (asing), namun juga usaha untuk menguasai. Setiap objek "asing" ini dilukiskan dengan ciri-ciri: aneh, unik, indah, bahkan mengancam yang dipelajari, dipahami, dan selanjutnya difamilierkan. Ciri-ciri ini ditetapkan terutama sebagai kontrol pembedaan Timur sebagai liyan yang asing (other)dan dari Barat sebagai diri yang dikenal (self). Dalam konteks kolonialisme, pembedaan tersebut: (1) menandai suatu cara pemisahan hierarkis dan sentralistis, dan (2) mereproduksi kedua kategori wilayah (Barat dan Timur) itu sebagai lawan-lawan biner.

Produktivitas wacana itu kemudian membentuk hegemoni kultural, yang secara universal menempatkan Barat lebih unggul dari Timur. Persoalannya, pengetahuan Barat yang semula dihasilkan dari kegiatan riil (empirik) itu, pada perkembangannya menjadi sekedar kisah imajinasi bikinan, ciptaan, dan konstruksi yang didasarkan pada wacanawacana ketimuran yang telah ada sebelumnya. Tema-tema tentang Timur, dalam hal ini tidak hanya menjadi "objek" eksotis yang dijual layaknya sebuah komoditas, namun lebih jauh lagi diarahkan pada pelembagaan wacana ketimuran yang hegemonik tentang citra eksotis itu. Said (2001:70) menyatakan: "beberapa objek "khas" hadir diciptakan 
oleh pikiran dan objek-objek tersebut sementara nampak bereksistensi secara objektif dan itu ternyata hanya memiliki realita fiktif saja”. Dalam hal demikian, menurut Turner (2006:77) wacana kolonial terbentuk dan cenderung menekankan pembedaan Timur $><$ Barat, sesuatu yang kemudian menjadi khas dalam struktur pengetahuan Barat.

Pada era revolusi di Indonesia, muncul budaya-budaya perlawanan terhadap sistem kolonialisme khususnya oleh intelektual pribumi, yang dalam mitos eksotisme Timur diberikan pemahaman dekonstruktif terhadapnya, terutama melalui ragam argumen alternatif. Alatas (dalam Said, 1995:338) mengatakan pribumi (Timur) harus sadar bahwa ketika mereka diwacanakan sebagai kaum pemalas, itu sama artinya dengan membentuk wacana dominasi terhadapnya dan didominasi berarti dikuasai. Menurut Said (1995:338-339) kesadaran serupa itu merupakan narasi optimistik yang bersifat kritis yang mampu memberikan dukungan bagi gerakan nasionalisme. Persoalannya, wacana perlawanan yang ditampilkan tidak selalu bisa menegaskan jati diri budaya yang benar-benar diharapkan.

Terjadinya konfrontasi-konfrontasi wacana sering memunculkan efek dramatis dari upaya dekolonisasi. Hal ini memberikan image buruk tentang ketidaksempurnaan dekolonisasi, terutama terhadap usaha meraih kebebasan dan pembentukan jati diri. Akibatnya, selain mentahnya perlawanan, juga menunjukkan bahwa para intelektual itu masih terjebak dan diperbudak oleh konsepsi-konsepsi kolonialisme (Barat), terutama berkenaan dengan imajinasi romantika masa lampau, tentang asal-usul nasional yang berusaha ditampilkan kembali. Citra eksotis kecenderungannya mengarah pada romantika dan mitos kehadiran kultur "asing". O leh karena itu, selain berkaitan dengan bayang-bayang nasionalistik mengenai jati diri dalam konteks dekolonisasi, terhadapnya dibangun kembali bahasa pribumi yang alkemis, yang diilhamkan hampir secara magis (Said, 1995:304). Pencarian kembali keaslian melalui gagasan-gagasan superterestrial para intelektual pribumi yang bersifat revolusioner itu selalu dikaitkan dengan mitos-mitos ketimuran sebagai sumber ataupun pijakan bagi upaya-upaya penemuan otentisitas jati diri yang hilang ditelan laju imperialisme Barat modern. Akibatnya, (meminjam istilah Fanon) "mengagumi Timur, itu sama sakitnya dengan membencinya" (Said, 1995:307). Keterjebakan ini kemudian menjadikan dilematis dalam karya-karya intelektual pribumi, terutama para penulis sastra, sekaligus menunjukkan bahwa dampak kolonialisme secara psikologis, sebagai pemanjaan yang berpusat pada diri emosional dalam konteks pencarian jati diri - yang objektif- otentik itu cenderung mengakar kuat.

Berkaitan dengan citra eksotis Timur dalam novel $R D P$, secara tematik dapat dimaknai bahwa novel tersebut menjadi ruang yang pencitraan Timur atau ketimuran senantiasa dikonstruksi melalui pemanfaatan efek-efek negatif dari sesuatu yang secara historis sebenarnya tidak diharapkan dan cenderung dipandang "other" sekaligus "mengancam". Adapun citra eksotis yang sudah dinarasikan menegaskan bahwa novel sebagai jenis karya sastra dapat turut ikut andil sebagai "aparat" dan "pendisiplin", 
yang lewat khas representatifnya dalam konteks poskolonialitas, mewakili suatu hasrat atau kehendak untuk "mengontrol", yang dalam beberapa nuansanya bertujuan "mengubah" sesuatu yang negatif menjadi positif. Kontrol tersebut dipadatkan melalui "solusi-solusi" yang dipersiapkan secara khusus, dalam ragam alternatif ataupun kemungkinan-kemungkinan, terutama untuk menguasai yang eksotik itu, sehingga bisa dihadirkan dalam bentuknya "yang familier".

Berdasarkan pemahaman latar belakang masalah, jika dikaitkan dengan kondisi poskolonialitas sebagai sebuah dampak, dua subbahasan yang dianggap sesuai dalam persoalan kontrol kuasa melalui "pencitraan" (citra eksotik) dalam novel RDP karya Ahmad Tohari dimaksud sebagai berikut. 1) Bagaimana reproduksi citra eksotis itu direpresentasikan dalam struktur narasi. 2) Bagaimana ambivalensi yang hadir kemudian sebagai dampak dari kondisi poskolonialitas.

Dalam artikel ini teori yang dipilih yaitu teori poskolonialisme. Definisi poskolonialisme adalah dampak yang ditimbulkan oleh kolonialisme. Menurut Loomba (2003:2), kolonialisme berkaitan dengan proses-proses penaklukan. Secara ideologis, dalam konteks kolonialisme Barat (Eropa), proses penaklukan terutama menggunakan kuasa pengetahuan (wacana). Said (2001:113-114) menegaskan wacana pengetahuan Barat terinstitusi dalam lembaga orientalisme selalu menempatkan Timur dalam posisi marginal, bukan sebagai objek, bahkan sebagai "tumbal".

Loomba (2001:87-88) membagi produksi pengetahuan kolonialis dalam beberapa proses, di antaranya: (a) melibatkan konflik dengan marginalisasi, sistem pengetahuan dan keyakinan yang terjajah, juga pandangan-pandangan yang bertentangan dengan negara asal (Eropa); (b) melibatkan kebrutalan dan perbedaan kultural, pengaburan posisi-posisi "murni" dari "diri" dan "pihak lain"; dan (c) dihasilkan melalui negosiasi-negosiasi dengan memasukkan gagasan-gagasan pribumi, bahwa pada tingkat yang sangat praktis, kaum kolonialis bergantung pada pribumi untuk memperoleh akses ke tanah-tanah "baru", dan rahasia-rahasia mereka. Reproduksi pengetahuan serupa ini kemudian membentuk citra-citra yang khas dalam wacana kolonial. Oleh karena itu, wacana kolonialisme harus dipahami sebagai situs kultural yang senantiasa merepresentasikan dan memelihara citra yang dikehendaki "peradaban" Barat, yang hingga masa kini masih menjadi bagian dari narasi-narasi besar, bahkan bagian dari pengalaman lokal yang sangat spesifik, dalam hal ini, sebagai dampak dari kolonialisme (poskolonialitas) (Smith,2005:10). Salah satu subwacana pengetahuan Barat yang turut mengkonstruksi Timur sebagai "yang lain" yaitu citra Timur yang eksotik (eksotisme).

Eksotisme berasal dari bahasa Latin exticus dari bahasa Yunani extikos, yang berarti dari luar. Sebagai kata sifat (exotically $\square$ adjective), eksotisme mencakup tiga hal berikut: 1) sesuatu yang berasal dari bagian dunia yang lain, wilayah yang asing, misalnya: tumbuh-tumbuhan tropis yang eksotik (from another part of the world; foreign: exotic tropical plants in a greenhouse); 2) suatu cara berbeda atau tidak biasa 
dalam membangkitkan minat; menggairahkan, asing, aneh, dan bersinonim dengan fantastik (intriguingly unusual or different; excitingly strange: "If something can be explained simply, in a familiar way, then it is best to avoid more exotic explanations". See synonyms at fantastic); dan 3) yang melekat pada tarian atau seni eksotis (ketelanjangan) (of or involving striptease: an exotic dancer). Sementara itu, sebagai kata benda (exoticness noun), eksotisme dapat diperhatikan dalam bentuk: 1) sesuatu yang memang terlihat eksotis (one that is exotic), dan 2) pemain sandiwara tarian telanjang (a striptease performer) (DUPD: Defeniton, Usage, and Pronunciation Dictionary).

Mengacu pada penjelasan di atas, wacana eksotisme dapat dipahami sebagai: suatu instrumen atau gagasan (Barat) dalam memandang dunia luar (Timur) sebagai yang eksotik, asing, aneh, primitif, fantastik, erotik, penuh gairah, klasik, liar, masih asli, khas, unik, menggiurkan, yang meski kesemuanya tidak familier, misterius, ataupun mengancam, merupakan tempat yang menjanjikan hadirnya pengalaman baru yang mengesankan. Defenisi tersebut berkaitan dengan ekspresi linguistik yang terkait dengan aspek material maupun non-material, seperti: spiritual, hasrat, ruang (tempat tinggal atau geografis), seni, bahasa, flora, fauna, dan manusia (tubuh, aktivitas, dan gagasan).

Eksotisme dalam Orientalisme, berkaitan dengan wacana tentang Timur "Yang Lain". Timur (Orient) sebagai invensi Eropa, merupakan tempat yang penuh romansa, makhluk-makhluk eksotik, kenangan-kenangan manis, pemandangan-pemandangan indah, dan pengalaman-pengalaman mengesankan (Said, 2001:1-2). Bagi Barat, Timur bukan hanya dekat, tetapi juga merupakan koloni-koloni Eropa yang terbesar, terkaya, dan tertua; tempat sumber-sumber peradaban dan bahasa-bahasanya, saingan budayanya, dan salah satu imajinya yang paling dalam, dan paling sering muncul tentang "dunia yang lain". Graham Huggan menjelaskan bahwa sesuatu (Timur) "yang eksotis" bisa diterima di "pusat" (Barat), tetapi tetap dipandang sebagai bagian dari garis budaya pinggiran (2001:20).

Dalam konteks poskolonialitas, citra eksotisme berkaitan dengan ego Eurosentris atau cara pandang Barat-penjajah yang telah menyerap dan cenderung dipertahankan dalam wawasan pengetahuan masyarakat bekas jajahan. Sebagai dampak kolonialisme, dalam hal ini, "Timur-terjajah" senantiasa dikonotasikan sebagai "yang eksotis", yang dihadirkan melalui idiom-idiom khas, dilapisi doktrin-doktrin tertentu, dan yang aspekaspek esensialnya - sadar ataupun tidak sadar-cenderung diarahkan pada suatu kepentingan politis dan ekonomis, yang karenanya justru menegaskan kembali dan mengamini "kolonisasi Barat".

Poskolonialisme, dengan demikian, merujuk pada pendapat Robert Young (dalam Hutcheon, 2004:287), adalah pembalikan dialektis, sebagai dekonstruksi terhadap paham orientalisme, sekaligus menganganggap bahwa sejarah tidak bergerak secara linier. Teori poskolonialisme dipandang sebagai teori yang mengungkapkan akibat yang ditimbulkan oleh kolonialisme. Teori poskolonialisme berkenaan dengan dampak kolonialisme, menurut Gandhi (2001:6-9), merupakan proyek disipliner guna menilik ulang, mengingat, dan secara krusial menyelidiki masa lalu kolonial. Fokusnya diarahkan 
pada kondisi historis, khususnya formasi diskursif yang bersifat dominatif dan hegemonik. Teori ini bertujuan: (1) menjelaskan bahwa teks memiliki kekuasaan yang bisa mendestabilisasi dasar-dasar pikiran dan kekuatan kolonial, (2) mengungkapkan antagonisme dan hasrat resiprokal dalam relasi kuasa antara Barat-"penjajah" (coloniser) >< Timur-“terjajah" (colonized) dan (3) menunjukkan bagaimana teks-teks itu meneguhkan efek kolonialisme, yang dikembangkan dalam "cara pandang" dan "keyakinan-" imperial tentang Other.

Berangkat dari pemamahan di atas jika dirujuk sebagai strategi pembacaan kritis terhadap dampak kolonialisme, maka teori poskolonialisme secara metodologis dimaksudkan untuk: (a) mengkaji kondisi-kondisi masyarakat terjajah pada elemenelemen internal yang tersubordinasikan, yang masih tetap ada dan terjaga oleh eksklusieksklusi dalam masyarakat pascakolonial; (b) mengungkapkan relasi kuasa oposisi antara "penjajah" >> "terjajah" dalam representasi wacana kolonial, yang senantiasa di antaranya menempatkan pihak "terjajah" sebagai yang tertindas; (c) menjelaskan kecenderungan yang menyebabkan dampak koloniaslisme itu-sadar tidak sadar-masih dipertahankan; dan (d) menunjukkan bahwa di dalam relasi oposisi "penjajah" >< "terjajah" terdapat retakan-retakan, sehingga memungkin untuk menolak atau menggugat balik relasi kuasa tersebut. Dalam potensi yang kemudian ini, teori poskolonialisme cenderung bersifat dekonstruktif.

\section{METODE}

Secara garis besar langkah-langkah metode dekonstruksi adalah: a) menghadirkan hierarki oposisi, memeriksa unsur-unsur kecil (yang "tidak diistimewakan") yang tidak dapat (sulit) dipastikan, penggantian yang hampir tidak dapat dipersepsi, yang mungkin luput dari pengamatan. Unsur-unsur kecil tersebut dimanfaatkan sebagai momen yang berpotensi menghancurkan sistem pengendalinya; dan b) melakukan pembalikan khusus terhadap posisi yang diistimewakan. Pada relasi oposisi semisal: maskulin $><$ feminin, rasional $><$ irasional, pengertian pertama cenderung diposisikan sebagai yang istimewa. "Keistimewaan" itu dibongkar dengan cara menunjukkan bahwa identitas yang "diistimewakan" tergantung kehadirannya hanya pada peminggiran pengertian yang "tidak diistimewakan"; dan itu menjelaskan bahwa keistimewaan tersebut sebenarnya milik pengertian yang disubordinasikan.

\section{HASIL DAN PEMBAHASAN}

\section{Citra Eksotis: Reproduksi Liyan}

Dalam konteks kolonial, representasi wacana sebagai upaya pencitraan merupakan kegiatan yang sangat penting kaitannya dengan operasi-operasi kekuasaan. Hal ini membuktikan bahwa legitimasi kekuasaan tidak semata-mata dikukuhkan secara fisik, namun juga secara kultural (tekstual). Said (2001:294) mengingatkan bahwa orientalisme modern telah membentuk suatu perbedaan gaya wacana tentang 
generalisasi-generalisasi Timur. Bagi Barat, yang memuliakan misinya adalah rasa dedikasi-intelektual; yakni sebagai manusia kulit putih. Generelisasi tersebut mengarah pada terciptanya perbedaan yang dilestarikan antara Timur dan Barat, dan terutama dominasi Barat atas Timur dalam semua keadaannya dalam kedua tradisi tersebut. Wacana ketimuran itu sendiri pada akhirnya menjadi bagian empiris dan spiritual Barat untuk menciptakan suatu tradisi panjang mengenai tanggung jawab kepemimpinan atas ras-ras Timur. Kritik Said di atas menunjukkan bahwa menjadi manusia kulit putih (Barat) adalah urusan mengukuhkan diri. Oleh karena itu, menjadi manusia kulit putih adalah cara paling kongkrit untuk hadir di dunia, suatu cara berpegang teguh pada realita, bahasa, dan pemikiran yang kemenyeluruhannya berinti pada kecenderungan menyudutkan Timur.

Persoalannya, jaringan mata rantai yang saling mengikat di atas justru membentuk fenomena yang timpang, yakni terbentuknya "kita" (Barat) sementara "mereka" outsider (Timur) dihilangkan (Said, 2001:297). Adapun kerangka pengetahuan dan budaya yang bersifat hegemonik ini dibangun di hadapan outsider-outsider yang aktual (koloni-koloni, orang-orang pribumi, dan segala yang berciri ketimuran) yang perannya dalam budaya adalah memberikan kepada apa yang secara konstitusional tidak cocok dengan mereka (Timur). Bisa dipahami kemudian bahwa representasi ketimuran itu lebih terutama ditujukan untuk mengukuhkan terciptanya pengetahuan tentang eksotisme Timur dalam paradigma Barat. Levinas (dalam Cavallaro, 2004:223) menyatakan bahwa cara pandang Barat dengan segala ideologi-ideologi dominannya, dengan sejumlah alasan yang telah mendefinisikan dirinya sendiri itu, oleh karennya, tidak bisa dilepaskan dari kenyataan di mana "other" (Timur) ditempatkan dalam posisi subordinate.

Dikaitkan dengan penjabarannya secara tematik dalam novel $R D P$, maka citra eksotis yang dominan merujuk pada kondisi-kondisi alami yang menyajikan citra "other" Dukuh Paruk sebagai ruang unik, asing, dan terbelakang. Spivak (via Ashcroft dkk., 2003:138) menjelaskan bahwa "Othering” mencakup asumsi tentang otoritas, „suara", kontrol atas ,katae, yakni perampasan dan penguasaan sarana-sarana interpretasi dan komunikasi. Ketegangan yang muncul dalam tematik teresebut adalah mitos utama pemberadaban Barat terhadap Timur (emansipasi), tentang "pengrusakan" dan "penyelamatan". Peradaban dalam hal ini cenderung otoritatif, disebabkan telah menghalangi perkembangan "Timur". Dalam kondisi itu, hadirnya "peradaban" justru seiring dengan: (a) terhapusnya bentuk-bentuk dan kemungkinan-kemungkinan bagi "tradisi" lain, (b) melibatkan penindasan dan atau peniadaan secara aktif terhadap bentukbentuk "otehrness", dan (c) mematikan bentuk-bentuk atau mode-mode alternatif lainnya. Berdasarkan penjelasan sebelumnya, dapat dipahami bahwa citra "eksotik" dalam novel $R D P$ ini merupakan suatu dampak kultural, dalam mana arogansi kolonialisme secara psikologis masih tertanam kuat baik itu disadari ataupun tidak, khususnya dalam konteks pascakonialitas.

Eksotisme alam misalnya, secara tematik masih mempertentangkan antara tradisi kehidupan dukuh Paruk yang "alami" dengan "budaya" dari luar tradisi dukuh Paruk 
yang dipandang oleh novel ini lebih beradab. Peretentangan tersebut terkesan ingin memberikan informasi tentang "sentralisasi yang ketat bagi kedaulatan alam atas kehidupan manusia", di sisi lain juga menunjukkan bahwa "kekuatan alam yang khas akan memberikan kepada manusia di sekitarnya kehidupan yang khas pula". Perbandingannya adalah, dihadirkannya "momen interpretatif" pemberadaban yang terwakilkan dalam simbolisme "akal budi" yang otoritatif (selera ilahi), secara ketat membaptis bahwa tradisi Dukuh Paruk adalah tradisi "yang terbelakang”. Dalam potensi demikian, medan pertentangan yang muncul menempatkan tradisi Dukuh Paruk berada lebih "rendah" dari otoritas pembatisnya, yakni "peradaban".

Alam dalam novel ini, melalui pandangan tokoh Rasus, merupakan bagian tidak terpisahkan dari masyarakat dukuh Paruk. "Kealamian" itu menghadirkan dukuh Paruk sebagai suatu tradisi "unik", yang penyajiannya cenderung bersifat statis: "di belakangku Dukuh Paruk diam membisu. Namun segalanya masih utuh di sana; keramat Ki Secamenggala, kemelaratan, sumpah-serapah, irama calung dan seorang ronggeng” (RDP-CBE:107). Pernyataan Rasus itu menggambarkan sebentuk cara pandang yang Barat-sentris bahwa, kondisi alam dukuh Paruk dengan segala eksotisme yang melekatinya dijadikan alasan terciptanya kehidupan dukuh Paruk yang terbelakang (dipenuhi koreng, minuman ciu, seruan cabul, dan kesewenangan berahi) (RDP-JB:383), dan itu seolah-olah demikian adanya. Mempertegas hal itu, dalam beberapa perulangan kisahan lain, kecenderungan serupa dipertahankan.

Musim hujan tiba. Sakarya menganjurkan orang-orang Dukuh Paruk melapisi atap-atap gubuk mereka dengan ilalang buat mengedap air hujan. Ilalang adalah atap yang sebenarnya. Dia menyerap panas ketika matahari terik. Sebaliknya, dia menyimpan kehangatan ketika udara di luar dingin dan kering. Tidur di atas pelupuh bambu di bawah atap ilalang adalah kenyamanan alarm yang tak mungkin terlupakan oleh setiap anak Dukuh Paruk. Kemarau datang menggantikan musim hujan. Hilang dan datang lagi. Atap ilalang yang menyelimuti orang-orang Dukuh Paruk sudah berusia lebih dari dua tahun, mulai lapuk.. ... Dindingnya diganti dengan anyaman bambu, ada jeruji di bagian depan juga dari bambu. Dukuh Paruk merambat perlahan seperti akar ilalang menyelusuri celah cadas. ... (RDP-JB:274).

Dukuh Paruk yang tidak pernah mengerti ilmu gizi mencukupi kebutuhan protein dengan belalang. Beri-beri dicegah dengan serangga. Bagi anak-anak pada umumnya pekerjaan mencari jangkrik dan belalang adalah bagian dunia bocah semata, dunia permainan. Tidak demikian halnya bagi anak-anak Sakum. Ketiganya berada dalam kesadaran penuh bahwa jangkrik dan belalang adalah urusan perut bagi seisi rumah. Maka mereka bekerja, bukan bermain. Tekun dan bersungguh-sungguh. Mereka tak tertarik akan cantiknya bulan di atas kepala. Bahkan mereka tidak melihat dua orang yang melintas menuju Dukuh Paruk (RDP-JB:302-303). 
Cuplikan narasi di atas menggambarkan kedekatan atau keakraban masyarakat dukuh Paruk dengan alam lingkungannya. Hewan, tumbuhan, dan suasana alam menjadi bagian yang tidak terpisahkan dari kehidupan mereka. Narasi tersebut pada akhirnya membentuk pengetahuan tentang karakter yang khas dukuh Paruk. Menjadi persoalan ketika oleh novel ini, kearifan masyarakat dukuh Paruk terhadap alam itu justru dipandang sebagai tradisi kehidupan dianggap terbelakang: “... dukuh Paruk, kecil dan menyendiri. Dukuh Paruk yang menciptakan kehidupannya sendiri" (RDPCBE:10), " ... dukuh Paruk merambat perlahan seperti akar ilalang menyelusuri celah cadas...." (RDP-JB:274), “dukuh Paruk yang tidak pernah mengerti ilmu gizi ..." (RDPJB:302).

Secara historis, ciri-ciri yang disematkan Barat tentang keterbelakangan Timur, seperti dijelaskan Said (2001:298-301), antara lain: tidak becus memerintah dirinya sendiri, memiliki jalan pikiran yang terlalu sederhana, mempercayai takhayul, dan perilaku yang tidak disiplin. Pencitraan seperti itu berada dalam dua jenjang, yaitu 1) dalam definisi, yang bersifat reduktif. dan 2) dalam realita. Koinsidensi mutlak ini bukanlah koinsidensi sederhana, disebabkan oleh: pertama, hanya mungkin terbentuk dari luar dengan menggunakan perbendaharaan dan alat-alat epistimologis yang dirancang untuk memahami inti dari segala sesuatu dan menghindari distraksi kejadian, situasisituasi, kondisi, dan pengalaman; dan kedua, merupakan kenyataan yang secara unik munculsebagai akibat dari metode, tradisi, dan politik yang saling bekerja sama. Di dalam kedua aspek pencitraan itulah, Timur senantiasa menjadi "objek" dalam pola pikir yang Barat- sentris.

Kecenderungan di atas direalisasikan dalam sistem pengetahuan, formasi kultural, dan relasi kekuasaan di mana konsep-konsep tersebut kemudian terletak. Ketika dihadapkan dengan konsepsi-konsepsi alternatif masyarakat Timur, realitas Barat dinyatakan dengan merepresentasikan sesuatu yang "lebih baik", mencerminkan "tatanan tinggi” pemikirannya yang maju, serta tidak mudah tunduk pada dogma, sihir, dan ketergesaan dari masyarakat primitif (Smith, 2001:57). Pesona ideoligis yang menghadirkan semacam kemampuan pedagogik itu, selanjutnya memposisikan cara berpikir Barat sebagai wakil dari kebenaran universal dan sebagai kriteria wajib masyarakat beradab, hal yang dipandang membedakannya dengan Timur. Oleh karenanya, dalam pandangan Barat-sentris, keterbelakangan adalah watak Timur, sekaligus Timur itu sendiri sebagai suatu gagasan yang harus dijadikan rujukan oleh siapa pun yang berurusan dengan atau menulis tentang Timur.

Dikaitkan dengan citra eksotik, maka lewat tema alam, tradisi Dukuh Paruk kemudian terdomestikasikan. RDP seperti hendak memberi pesan bahwa manusia untuk mempertahankan eksistensinnya harus memahami sekaligus menjinakkan alam lingkungan, atau bahwa manusia tidak akan dapat hidup dan mengembangkan potensinya secara utuh tanpa mengenal sekaligus menguasai alam. Persoalannya, pernyataan tentang keakraban Dukuh Paruk terhadap alam ini sifatnya terkesan impersonal, sebuah abstraksi metafisik. Hal ini dapat dilihat, bahwa ketika "keakraban" dukuh Paruk terhadap alam 
digunakan untuk membentuk ciri eksotik terhadapnya, $R D P$ turut menyematkan kepada mereka sebagai tradisi tidak berpendidikan, tidak berkembang, dan bahkan terbelakang. Justru, jika dikaji lebih jauh, penyajian "keakraban" masyarakat dukuh Paruk terhadap alam itulah kemudian membuka kemungkinan bahwa "peradaban" memang senantiasa ingin tampil sebagai sentral yang berdaulat. Dalam konsep tematik seperti itu, tradisi dukuh Paruk hadir dalam citranya "yang eksotik", dan akan senantiasa tunduk di bawah kuasa "peradaban", sekaligus melegitimasi "yang beradab" untuk "berhak" mengatakan bahwa: "kebodohan memang pusaka dukuh Paruk (RDP-CBE:24). Berikut adalah sebagian data yang mendukung penyataan tersebut.

Kesalahan harus ditimpakan kepada bakteria jenis pseudomonas coccovenenans yang ikut tumbuh pada bongkrek dalam peragian. Bakteria itu menghasilkan racun kuat yang menjadi cikal-bakal kematian orang yang makan tempe bongkrek. Tetapi orang akan sia-sia menyampaikan pengetahuan ini ke Dukuh Paruk. Di sana orang begitu yakin asam tembaga adalah satu-satunya penyebab racun bongkrek. Demikian, dengan menghindarkan perkakas tembaga orang Dukuh Paruk masih membuat tempe bongkrek (RDP-CBE:33)

Kemelaratan di sana terpelihara secara lestari karena kebodohan dan kemalasan penghuninya. Mereka hanya puas menjadi buruh tani. Atau berladang singkong kecil- kecilan. Bila ada sedikit panen, minuman keras memasuki setiap pintu rumah. Suara calung dan tembang ronggeng meninabobokkan Dukuh Paruk. (RDP-CBE:86).

Adapun semesta alami "yang khas" itu, oleh novel $R D P$, sering dikaitkan dengan simbol-simbol material yang membantu terbentuknya kesan mistis dalam pola kebatinan masyarakat dukuh Paruk, misalnya penafisran-penafsiran mereka terhadap benda-benda dan perubahan-perubahan yang terjadi di alam. Hal yang harus dipahami di sini adalah hadirnya otoritas selektif, yang penguatan terhadap unsur-unsur tradisi sebagai yang mistis senantiasa berada dalam "pengawasan" momen interpretatif "peradaban baru" yang "berbeda".

Apabila ayunan ke kanan bercorak hitam misalnya maka ayunan ke kiri dalam banyak hal adalah kebalikannya, putih. Itu nasihat Sakarya kepada puak Dukuh Paruk. Tetapi pengetahuan semacam itu bagi orang Dukuh Paruk adalah ngelmu, bukan ilmu. Pemahamannya tidak pernah menjadikan orang disana sampai kepada pengetahuan praktis. Tak pernah membumi dan selalu dibungkus dengan pandangan-pandangan mistik (RDP-JB:312)

Berkitan dengan pola kebatinan, tradisi dukuh Paruk dikondisikan percaya bahwa alam tidak saja sesuatu yang tampak dalam penglihatan mereka, tetapi di luar bentukbentuk fisikal itu terdapat "alam lain". Kehadiran alam lain itu hanya bisa ditangkap atau dipahami melalui bentuk-bentuk material: "Gumpalan abu kemenyan pada nisan kubur 
Ki Secamenggala membuktikan polah tingkah kebatinan orang Dukuh Paruk berpusat di sana." (RDP-CBE:10). Alam fisikal, dalam hal ini, menjadi simbolisme material yang dipandang mampu memberikan petunjuk akan kebenaran transenden, sebagai pola kebatinan masyarakat dukuh Paruk. Persoalannya, "kealamian" ini juga dipakai untuk mewacanakan bahwa masyarakat dukuh Paruk adalah masyarakat irasional, percaya terhadap hal mistik ataupun takhayul, dan alam yang menjadi mediasinya.

Dalam konteks Barat-sentris, kebiasaan itu menunjukkan ciri tradisi masyarakat "primitif" atau masyarakat terbelakang. Hasil akhirnya, khususnya dalam penilaian Rasus, adalah dengan tradisi yang demikian itu masyarakat dukuh Paruk dianggap tidak pernah mampu bahkan selalu salah mengartikan atau memaknai kehidupan dalam hubungan mereka dengan alam. Hal itu pula yang dipakai Rasus sebagai alasan mengapa masyarakat dukuh Paruk tetap bodoh, kotor, dan cenderung liar. Representasi "ketimuran" itu, jelas secara tidak langsung mengamini terciptanya relasi kuasa oposisi sekaligus ruang marginalisasi, yang tradisi masyarakat dukuh Paruk secara hierarkis "tertinggal" atau "berbeda" dengan tradisi "yang berada" di luarnya. Oleh karena itu, Rasus, sebagai orang asli dukuh Paruk, merasa perlu untuk keluar dari wilayah pedukuhannya untuk mencari "cermin" yang berbeda. Di balik semua itu, RDP mengisahkan bahwa sekembalinya nanti Rasus berniat "mengubah" corak tradisi yang khas dukuh Paruk untuk menjadi lebih "beradab". Niatan untuk mengubah sesuatu menjadi lebih itu jelas merupakan sebentuk upaya "emansipatif'. Persoalannya, dalam konteks emansipasi itu, tersirat pula niatan tertentu untuk menghadirkan budaya yang "beradab" sebagai sebuah "acuan" tunggal, yang ciri-cirinya bisa dipastikan bertentangan dengan tradisi dukuh Paruk.

Dulu aku demikian yakin membiarkan Dukuh Paruk apa adanya adalah arif. Sekarang dengan kesadaranku sendiri pikiranku berbalik; membiarkan Dukuh Paruk tetap cabul, kere, dan dungu adalah bertentangan dengan misi utama kemanusiaan itu sendiri. Di sana adalah orang-orang sepuak yang berjumlah tidak lebih dari tujuh puluh kepala. Menggembalakan mereka mestilah bukan suatu pekerjaan yang terlampau sulit. (RDP-JB:382)

Karena tak pernah atau tak mampu mengembangkan akal budi pula, tanah airku yang kecil sesungguhnya tak pernah berusaha menyelaraskan diri dengan selera Ilahi. ... Dukuh Paruk harus kubantu menemukan dirinya kembali, lalu kuajak mencari keselarasan di hadapan Sang Wujud yang serba tanpa batas (RDPJB:360).

Dihadirkan dengan banyak karakter bercirikan masyarakat terbelakang, sesuai cara pandang Barat terhadap Timur, menunjukkan bahwa RDP, melalui Rasus, telah memposisikan tradisi Dukuh Paruk sebagai suatu tradisi other. Kerakter other itu didukung dengan segala citra eksotik (irrasional, mistis, dan primitif) yang melingkupi tradisi Dukuh Paruk. Pembenaran kesan terbelakang itu, menjadikan novel ini sebagai novel yang turut melestarikan wacana kolonial. 
Dalam konteks poskolonialitas, berkaitan dengan other itu, dapat dilihat dari selalu dihadirkannya informasi statis tentang eksotisme alam Dukuh Paruk sebagai "pedukuhan sempit", "sebuah gerumbul kecil", "daerah paling sunyi", "kecil dan menyendiri", "tua dan masih naif", dan tempat bermukimnya sekumpulan masyarakat "yang sejak kelahirannya tak pernah mampu menangkap maksud tertinggi kehidupan". Karekter itu tidak saja menyajikan sebentuk eksotisme, namun juga sekaligus memperkuat eksotisme itu sendiri. Persoalannya, sajian eksotisme alam itu cenderung dibangun lewat kesan-kesan puitis sebentuk "hasrat" tersembunyi di belakangnya, yakni sebentuk kuasa estetis (kaum orientalis) dalam menghadirkan "sesuatu" sebagai "sang lain", yang menggambarkan kuasa representasi dalam menghadirkan wilayah-wilayah "khas" senantiasa dalam ruang-ruang yang khusus (khas) pula. Adapun kehadiran "sang lain" diupayakan sebisa mungkin memunculkan hasrat "menggembalakan" terhadap "ruang khusus" yang dimaksud. Efeknya, terlegitimasi sebagai other, tradisi Dukuh Paruk tidak hadir sebagai wilayah yang "polos" bagi "sang petualang", tetapi dilekatkan kepadanya nilai-nilai tertentu.

Hasil akhir dalam eksotisme alam ini, RDP membaptis bahwa masyarakat dukuh Paruk adalah masyarakat yang tidak pernah benar-benar bisa menangkap makna tertinggi dari kehidupan dan "tak pernah bersungguh-sungguh mengembangkan akal budi sehingga tidak tahu bahwa dia seharusnya menyingkirkan kurap dan cacing yang menggerogoti anak-anak, serta kebodohan yang hanya membawa kemelaratan turuntemurun" (RDP-JB:394). Pernyataan ini mengasumsikan bahwa penisbahan diri terhadap alam haruslah disertai dengan pertimbangan-pertimbangan yang rasional. Di luar itu semua, seolah menjadi sah menempatkan dukuh Paruk sebagai other. Dikaitkan dengan kondisi pascakolonialitas menjadi dilematis kemudian ketika dari beberapa proporsi narasi eksotisme alam yang disajikan $R D P$ membentuk representasi other itu justru sebagian besar dibebankan dan berasal dari ungkapan-ungkapan dan pikiran-pikiran Rasus yang berasal dari Dukuh Paruk sendiri.

Dipahami di sini bahwa setiap aktivitas yang berorientasi "orientalisme" (kolonialisme) bukan lagi murni dihasilkan oleh pihak Barat secara langsung, yang biasanya ditujukan mencari apa yang eksotis dan potensial dalam bentuknya yang riil tentang Timur, melainkan eksotisme itu sudah menjadi konsumsi budaya yang Timur terjebak dalam hegemoni Barat-sentris tentang image eksotisme (Timur) itu sendiri. Image dimaksud adalah segala macam karakter ketimuran, yang senantiasa diposisikan sebagai other, berkaitan dengan "keanehan", "keterbelakangan", "keunikan”, dan lainlainnya, yang keseluruhannya diharapkan menggugah perhatian bagi siapa saja agar meyakininya sebagai yang nyata "ada", meskipun sesuatu itu sebenarnya belum tentu ada atau bahkan tidak sesuai dengan kenyataannya.

Secara tematik wacana eksotisme alam, menyiratkan relasi hierarkis Barat $><$ Timur, bahwa untuk menjadi manusia yang beradab, haruslah bisa memberikan porsi yang sintetis antara pikiran (budaya) terhadap emosi (alam), antara yang negatif dan yang 
positif, juga antara yang ideal dan yang nyata. Ketegangan di antaranya sekaligus memberikan ruang dinamika penafsiran dalam hegemoni relasi kuasa yang menyertainya. Misalnya, alam fisikal (alam fisik, yang di dalamnya terdiri dari manusia, flora, fauna, dan benda-benda material lainnya) dan wilayah mistik. Dalam relasi kuasa oposisi itu, gagasan yang disampaikan oleh novel ini jelas tidak lebih dari suatu upaya mengamini tradisi kolonialisme dalam konteks pengetahuan dan peradaban Barat (khususnya tentang wacana ketimuran), yang pada intinya senantiasa mempertahankan perbedaan hierarkis antara penjajah dan terjajah, antara self dan other secara timpang.

Dalam konteks relasi oposisi itu pula, novel RDP terkesan mensyaratkan bahwa tanpa adanya suatu penggerak (emansipator) yang bisa memberikan mekanisme emansipatif terhadapnya, maka mustahil "peradaban" di Dukuh Paruk bisa terwujud, khususnya terhadap tradisi Dukuh Paruk yang cenderung dihadirkan sebagai yang "eksotis". Kenyataan ini jelas secara tidak langsung menuntut hadirnya "pihak luar" dalam upaya-upaya emansipatif tersebut. Di sinilah novel RDP melalui tokoh Rasus memposisikan dirinya sebagai agen atau emansipator. Dengan kehadiran Rasus sebagai emansipator itu, RDP seolah-olah di satu sisi ingin menunjukkan bahwa semua aktivitas manusia, baik rasional maupun emosional; kemenyeluruhannya dapat membentuk budaya (yang beradab) jika itu didominasi oleh gerak kuasa aktif manusia terhadap alam, bukan sebaliknya. Oleh karena itu, di sisi lain dalam kehidupan yang berbudaya itu harus bergerak dan berpijak menuju satu sumber kuasa, artinya "menyelaraskan diri dengan selera Ilahi” (RDP-JB:394). Kecenderungan tersebut memungkinkan untuk menyatakan bahwa $R D P$ adalah sebuah karya emansipatif, layaknya karya-karya para orientalis, yang setiap menyajikan narasi-narasi pencerahan senantiasa berpijak pada eksotisme ketimuran.

Gagasan eksotisme alam dalam novel $R D P$, dengan demikian, erat kaitannya dengan relasi kuasa berkenaan dengan simbolisme material yang tujuan utamanya niatanniatan pemberadaban. Niatan-niatan ini tidak hanya berkontemplasi dengan kuasa rasional (ilmu pengetahuan) tertentu, tetapi juga berkaitan dengan nilai-nilai religiusitas (agama). Pada peleburan keduanya, pikiran dan emosi ataupun rasioanalitas dan religiusitas itu diharapkan bisa membentuk perubahan kultural, terutama dalam tingkah pola kehidupan tradisi dukuh Paruk, dan yang senantiasa "menyelaraskan diri dengan selera Ilahi" (bagian akhir dari RDP episode JB). Namun demikian, hal itu jelas bertentangan dengan tradisi dukuh Paruk yang pola kebatinan masyarakatnya terwakilkan dalam simbolisme material yang lebih mempercayakan eksistensi dirinya pada kuasa alam melalui mediasi-mediasi yang justru oleh novel ini dianggap tidak rasional dan tidak didasari selera Ilahi, seperti: "Kubur Ki Secamenggala yang terletak di punggung bukit kecil di tengah Dukuh Paruk yang menjadi kiblat kehidupan kebatinan mereka" (RDP-CBE:10). Oleh karena itu, menjadi paradoks kemudian ketika perubahan menjadi "yang beradab" itu tradisi Dukuh Paruk terkesan menjadi "sarana". Kemungkinannya, justru dalam wilayah "yang beradab" itu masyarakat dan tradisi Dukuh Paruk semakin diperkukuh statusnya secara statis, yakni senantiasa sebagai other, namun 
yang juga sekaligus menjadi penentu kehadiran tradisi lain di luar Dukuh Paruk sebagai self.

Dengan demikian, Citra eksotisme ketika dikaitkan dengan hasrat emansipatif itu menjadi tidak lebih dari sebuah niatan menguasai dalam batasan-batasan hegemoni tertentu. Melaluinya, sebentuk pandangan institusional kemudian mengikat, "yang eksotis" dijustifikasi kembali sebagai other, senantiasa sebagai "ancaman". Dengan demikian, menjadi jelas pula, bahwa selera Ilahi yang ditawarkan sebagai "solusi" oleh novel RDP ini, kadar emansipatif tersebut cenderung hadir dalam makna yang berkebalikan. Dalam hal ini, selera Ilahi tidak lebih hanya sebuah alat atau sarana hasil rekonstruksi berkesinambungan tentang penciptaan sekaligus penjinakan atas ancaman-ancaman, di mana "other" senantiasa dihasilkan dan dikontrol. Di sisi lain, pemahaman emansipatif sebagai "solusi" itu justru menjadi ancaman bagi tradisi-tradisi lain misalnya tradisi ronggeng dukuh Paruk, seperti dalam trilogi novel RDP ini.

\section{Citra Eksotis: Ambivalensi}

Dalam bukunya Orientalism, Edward Said mengingatkan bahwa dalam pandangan Barat, dunia Timur merupakan sesuatu yang lebih dari apa yang diketahui secara empiris mengenainya (2001:72). Pemahaman Barat terhadap budaya Timur dipenuhi oleh asosiasi-asosiasi jahil yang demikian kompleks, namun justru itu cenderung tidak cermat. Ada dua hal pokok yang ditekankan dalam pemikiran Barat itu yakni; (1) garis demarkasi antara Barat dan Timur, dan (2) corak dunia Timur sebagai bencana (ancaman). Yang pertama, menegaskan bahwa kekuatan ilmu pengetahuan Barat -dengan kemampuannya menciptakan wacana-wacana tentang Timur sebagai suatu „kebenaran ${ }^{\text {ee }}$ telah menempatkan dunia Barat secara hierarkis di atas Timur. Yang kedua, kuasa rasionalitas Barat dalam menilai dan menetapkan ekses-ekses Timur sebagai gangguan yang merongrong ataupun mengancam. Timur adalah dunia yang misterius dan cenderung berkebalikan dengan nilai-nilai normatif.

Pernyataan Said di atas menunjukkan bahwa dalam pertunjukkan kekuasaan, Barat lebih mementingkan dirinya sendiri dalam tradisi taksonomis, yakni kebiasaannya merepresentasikan wilayah-wilayah, ras-ras, dan bangsa-bangsa di luarnya dengan tujuan menjadikan posisi Barat lebih unggul. Kondisi tersebut jika dikaitkan dengan wacana eksotisme, Timur dalam pandangan Barat dapat dimaknai dalam dua hal, yakni (1) sebagai dunia lama tempat kembali, dan (2) sebagai tempat yang sama sekali baru. Benturan-benturan yang terjadi dalam persinggungan antara Barat terhadap Timur dalam dua pemahaman tersebut memunculkan sejumlah paket-paket khas, seperti: catatan perjalanan, dongeng, streotip-streotip, dan konfrontasi polemik. Pada akhirnya, paketpaket khas itu menjadi apa yang disebut oleh Said (2001:75) "sebagai „teropongteroponge yang digunakan untuk mengalami dunia Timur."

Dalam konteks poskolonial, Gandhi (2001:7) mengingatkan bahwa kontinuitas perspektif Barat sebagai dampak kolonial memiliki kecenderungan menyajikan versi- 
versi pengetahuan yang serupa dan agensi yang diproduksi untuk merespon tekanantekanan pertikular dalam segenap pengalaman kolonial. Dalam menanggapinya, poskolonialisme dapat berfungsi sebagai resistensi teoritis terhadap amnesia praktikpraktik kolonial. Proses yang perlu ditindaklanjuti adalah menilik-ulang, mengingat kembali, dan secara krusial menyelidiki masa lalu kolonial, yang tujuannya menyingkap hubungan antagonisme antara penjajah (Barat-Coloniser) dan terjajah (Timur-Colonised).

Persoalannya, jika dikaitkan dengan proses dekolonisasi, khususnya terhadap gerakan-gerakan anti-kolonial, seringkali diiringi pula dengan hasrat untuk melupakan pengalaman kolonial pada masa lalu. Kehendak untuk melupakan ini bahkan cenderung mengambil sejumlah bentuk-bentuk historis yang dilatarbelakangi oleh berbagai macam motivasi kultural dan politis. Hal yang terjadi kemudian, amnesia poskolonialitas sering menimbulkan gejala adanya dorongan swapenciptaan sejarah atau kebutuhan untuk memulai awal baru, yang tujuannya untuk menghapus berbagai kenangan menyakitkan tentang subordinasi kolonial.

Dampak lain yang muncul, menurut Gandhi (2001:5) adalah gerakan-gerakan antikolonial itu seringkali terjebak dan tidak bisa keluar dari persoalan yang dihadapinya, terutama dalam upayanya melepaskan beban-beban warisan kolonial mereka. Dalam hal demikian, poskolonialis ditandai serangkaian moods dan formasi kultural ambivalen, yang mengiringi periode transisi dan translasi. Hal ini terutama merupakan peristiwa „kehadiran ${ }^{\text {ee }}$ yang dirayakan dalam makna inkarnasi yang mitis. Oleh karena itu, para pewaris pengaruh kolonial ini, dalam arti tertentu, penuh dengan kebingungan dan ketakutan akan kegagalan yang menyertai kebutuhannya memuaskan beban pengharapan sejarah. Seperti diungkapkan Jameson (1991:39) bahwa dampak kolonialisme adalah cyborg, para pewaris yang terimbas akan terganggu oleh "sesuatu semacam perintah" untuk menumbuhkan organ-oragan baru, mengembangkan sensor dan tubuh dalam matra-matra baru, yang sebelumnya tidak pernah terbayangkan, bahkan mustahil dibayangkan. Dalam memenuhi kebutuhan itu, poskolonialitas dipaksa menegosiasikan pelbagai kontradiksi yang muncul dalam keterlambatan historisnya, yakni: (1) poskolonialitasnya atau derivasi politis dan kronologisnya dari kolonialisme, dan (2) kewajiban kulturalnya untuk menjadi kokoh dan inventif secara bermakna.

Akibatnya, seperti diungkapkan oleh Albert Memmi (Gandhi, 2001:8-9) dampak kolonial secara fundamental menghadirkan sebentuk imajiansi yang terperdaya, bahwa arsitektur dunia baru akan dapat muncul secara ajaib dari reruntuhan fisik kolonialisme, subjek-subjek yang merasa dirinya jaya dalam kondisi ini menganggap remeh keyakinan yang kuat secara psikologis terhadap masa lalu "yang kolonial" di atas masa kini "yang poskolonial".

Dari penjelasan di atas, dampak kolonialisme ini terutama bersinggungan dengan strategi-strategi disipliner ideologis, yakni masih adanya dorongan untuk "menciptakan" subjek-subjek "tertentu" yang kemudian harus patuh, yang ditundukkan oleh gagasangagasan abstrak mengenai nilai-nilai etika, moral, dan estetika, yang kebergunaannya 
justru sebagai "belenggu" bagi subjek-subjek tertundukkan. Penertiban ini jelas merupakan praktik-praktik yang bertujuan tidak saja memilah antara Barat dengan Timur dalam konteks kolonial, namun sekaligus sebagai sebentuk eksekusi yang dalam subjek-subjek "tertentu" itu diupayakan melebur menjadi sebuah "kesatuan", sehingga tampil membentuk peradaban "baru" dalam tradisi yang "baru" pula. Dalam konteks pascakolonialitas, kecenderung itu bukan lagi sebagai bentuk dominasi langsung subjek Barat terhadap Timur, namun justru lebih diarahkan pada pola pikir (perspektif) yang Barat-sentris yang secara hegemonik merasuki subjek-subjek Timur. Dengan demikian bisa dikatakan, citra eksotis itu menggambarkan suatu kondisi dalam "Timur menimurkan Timur".

Demikianlah komparatif di atas, bahwa dampak kolonialisme menjadi sinonim kembali dengan apa yang tampak sebagai ketidaksetaraan ontologis antara Barat dan Timur yang dilematis. Secara tematik, hal dimaksud dapat dicermati pada terbangunannya statemen-statemen ketimuran, berkaitan dengan relasi oposisi Barat $><$ Timur, dari "suara" subjek Timur itu sendiri. Adapun "objek" yang paling dominan dalam $R D P$, berkaitan statemen-statemen ketimuran dalam kaitannya dengan wacana eksotisme itu sendiri adalah tradisi Dukuh Paruk yang alami. Ditetapkannya tradisi Dukuh Paruk sebagai objek wacana ketimuran itu didasarkan pada beberapa hal: (1) hampir keseluruhan narasi yang dihadirkan berkaitan dengan tradisi Dukuh Paruk dalam konotasi "other", (2) relasi oposisi yang terbangun dalam konteks Barat $><$ Timur juga lebih dominan mengarah pada upaya emansipasi terhadap tradisi Dukuh Paruk, (3) novel RDP sendiri menghabiskan begitu banyak waktunya dalam narasi yang mengisahkan kehidupan orang-orang Dukuh Paruk dalam segala keterbelakangannya, akan tetapi (4) dari aspek tematik yang terbangun, yang kecenderungnya mengarah pada niatan emansipatif itu, justru tidak saja mengulang narasi kolonial melalui citra "eksotik" yang Dukuh Paruk dihadirkan sebagai objek (terjajah), tetapi sekaligus secara tidak terelakkan posisi objek itu menjadi pijakan bagi sang emansipator untuk bisa tampil sebagai subjek (penjajah). Artinya: (1) tanpa kehadiran eksotisme tradisi Dukuh Paruk serupa itu, maka tidak akan pernah ada budaya luar Dukuh Paruk sebagai pembedanya, (2) tanpa ada objek yang diemansipasi maka tidak akan pernah hadir sang emansipator, dan (3) justru dalam posisi itulah, "objek terjajah" (other) mendapatkan posisinya lebih utama dari "subjek penjajah", sebuah kondisi yang paradoks.

\section{SIMPULAN}

Kesimpulan dari hasil pembahasan citra eksotisme dalam novel RDP karya Ahmad Tohari yang dikaji dari sudut pandang poskolonialisme adalah masih kuatnya hegemoni wacana kolonialisme sebagai sebuah dampak, terutama berkaitan dengan tema-tema yang terbangun di dalam novel $R D P$, di antaranya sebagai berikut. Pertama, berkaitan dengan wacana eksotisme yang di dalamnya relasi oposisi antara penjajah (Barat) $><$ terjajah (Timur) masih dipertahankan. Relasi-relasi itu tidak saja dibangun dalam medan kuasa 
yang saling bertentangan, tetapi juga ada niatan-niatan peleburan terhadapnya. Persoalannya, dalam pertentangan dan peleburan itu perlakuan diskriminatif dan idiom streotip-streotip masih diturutsertakan. Kedua, berkaitan dengan "hasrat emansipatif". Dalam kemampuannya mengetengahkan narasi-narasi kehidupan masyarakat "pinggiran" novel $R D P$ sebagai salah satu karya yang paham benar akan persoalan tersebut. Hanya, kecenderungan ambiguitas justru muncul dari "jawaban" atau solusi-solusi yang ditawarkannya. N ovel ini tidak hanya berusaha mendorong masyarakat "pinggiran" itu bergerak menuju "pusat", tetapi ada niatnya untuk membaratsentriskan Timur, Timur secara permanen akan senantiasa menggantungkan dirinya pada budaya Barat. Dalam hal ini, tradisi Timur senantiasa berada dalam belenggu Barat. Ketiga, berkaitan dengan cara pandang yang Barat-sentris. Dalam hal ini, "Timur" yang dihadirkan sebagai yang eksotis, dengan segenap idiom-idiom ketimurannya, tidak lagi dipahami sebagai yang selalu disuarakan dari pihak Barat. Dengan kalimat lain, pandangan tentang "timur yang eksotis" itu juga telah menjadi bagian dari suara-suara yang diamini oleh Timur itu. Hal ini menjadi suatu bentuk nyata dalam pengetahuan atau cara pandang yang Baratsentri itu telah menjadi konsumsi Timur dalam "mengukur" dirinya, sekaligus menunjukkan kuatnya hegemoni wacana kolonial.

Dari beberapa kesimpulan di atas, dampak kolonialisme menggambarkan suatu kondisi bahwa Timur "yang eksotis" masih "dirindukan" posisinya sebagai objek yang berbeda, yang asing, yang indah, bahkan mengancam. Dengan demikian ketika dihadirkan kembali bisa menjadi familier. Negosiasi yang mendukung dalam hal ini adalah ditampilkannya defenisi-defenisi moralitas, religiusitas, dan etika, yang dalam novel $R D P$ ini merujuk pada kuasa "selera ilahi". Persoalannya, kuasa "selera ilahi" ini cenderung berfungsi sebagai "agen" sekaligus "aparat" yang berhak menentukan kapasitas, kualitas, bahkan kehidupan Timur "yang eksotis". Nuansa ambiguitas yang akhirnya muncul adalah ketika wacana pemberadaban dalam konteks "selera ilahi" itu dikumandangkan, justru pada saat bersamaan kedudukan atau identitas Timur tetap dipertahankan, bahkan kian tereksotiskan. Dengan kalimat lain, Timur "yang eksotis" itu akan selalu dan masih terus "pada tepi paling pinggir", dan karenanya bisa dikatakan pula bahwa "Timur" menimurkan Timur itu tidak akan pernah "pasca".

\section{DAFTAR PUSTAKA}

Aschroft, B., Garreth Griffiths, dan Helen Tiffin. 1995. The Post-Colonial Studies Reader. London and New York: Routledge.

Cavallaro, D. 2001. Critical and Cultural theory; Thematic Variations. London: The Athlone Press. Diterjemahkan dalam judul: Teori Kritis dan Teori Budaya. 2001, oleh Laily Rahmawati. Yogyakarta: Niagara.

Gandhi, L. 1998. Postcolonial Theory A Critical Introduction. London: Allen and Unwin. Diterjemahkan dalam judul: Teori Poskolonial: Upaya Meruntuhkan Hegemoni Barat. 2001, oleh Yuwan Wahyutri dan Nur Hamidah. Yogyakarta: Qalam.

Huggan, G. 2001. The Post-colonial Exotic: Marketing the Margins: London: Routledge. 
Hutcheon, Linda. 1992. A Poetics of Posrmodenism.: History, Theory Fiction. $\quad$ Routledge: New York and London.

Loomba, A. 2000. Colonialism/Postcolonialism. New York: Routledge. Diterjemamahkan dalam judul; Kolonialisme/Pascakolonialisme, 2003, oleh Hartono Hadikusumo. Yogyakarta: Bentang Budaya.

Said, E. W. 1979. Orientalism. New York: Vintage Books. Diterjemahkan dalam judul:

Orientalisme. 2001, oleh Asep Hikmat. Bandung: Pustaka.

Said, E. W. 1981. Covering Islam: How the Media and the Experts Determina How We See the Rest of The World. New York. Pantheon Books. Diterjemahkan dalm judul: Covering Islam, Bias Liputan Barat Atas Dunia Islam - 2002, oleh A. Asnawi dan Supriyanto Abdullah. Yogyakarta: Ikon Terlitera.

Said, E. W. 1993. Culture and Imperialism. London, 20 Vaxhaull Brigde Road: Chatto and Windus Ltd. Diterjemahkan dalam judul: Kebudayaan dan Kekuasaan - 1995, oleh Rahmani Astuti. Bandung: Mizan.

Smith, L. T. 1999. Decolonizing Methodologhies, Research and Indegenous People. London: Zed Books. Diterjemahkan dalam judul: Dekolonisasi Metodologi - 2005 oleh Nur Cholis. Yogyakarta: INSIST press.

Spivak, Gayatri C. 1993. "Can Subaltern Speak?” on Colonial Discourse and PostColonial Theory. Williams and L. Chrisman eds.

Tohari, Ahamad. 2003. Ronggeng Dukuh Paruk. Jakarta: PT Gramedia Pustaka Utama.

Turner, Bryan S. 2006. Runtuhnya Universalitas Sosiologi Barat. Bongkar Wacana Atas Islam vis a vis Barat, Orientalisme, Postmodernisme, dan Globalisme. Yogyakarta: Ar-Ruzz Media. 